\title{
Synthesis and Characterization of Lithium-Substituted Cu-Mn Ferrite Nanoparticles
}

\author{
M. A. Mohshin Quraishi ${ }^{1}$ and M. H. R. Khan ${ }^{2}$ \\ ${ }^{1}$ Department of Physics, Manarat Dhaka International College, Dhaka 1212, Bangladesh \\ ${ }^{2}$ Department of Arts and Sciences, Ahsanullah University of Science and Technology, Dhaka 1208, Bangladesh
}

Correspondence should be addressed to M. A. Mohshin Quraishi; m.phys@yahoo.com

Received 5 July 2013; Accepted 29 August 2013

Academic Editors: H. Leiste and D. L. Sales

Copyright (C) 2013 M. A. M. Quraishi and M. H. R. Khan. This is an open access article distributed under the Creative Commons Attribution License, which permits unrestricted use, distribution, and reproduction in any medium, provided the original work is properly cited.

\begin{abstract}
The effect of $\mathrm{Li}$ substitution on the structural and magnetic properties of $\mathrm{Li}_{x} \mathrm{Cu}_{0.12} \mathrm{Mn}_{0.88-2 x} \mathrm{Fe}_{2+x} \mathrm{O}_{4}(x=0.00,0.10,0.20,0.30,0.40$, and 0.44$)$ ferrite nanoparticles prepared by combustion technique has been investigated. Structural and surface morphology have been studied by X-ray diffractometer (XRD) and high-resolution optical microscope, respectively. The observed particle size of various $\mathrm{Li}_{x} \mathrm{Cu}_{0.12} \mathrm{Mn}_{0.88-2 x} \mathrm{Fe}_{2+x} \mathrm{O}_{4}$ is found to be in the range of $9 \mathrm{~nm}$ to $30 \mathrm{~nm}$. XRD result confirms single-phase spinel structure for each composition. The lattice constant increases with increasing Li content. The bulk density shows a decreasing trend with $\mathrm{Li}$ substitution. The real part of initial permeability $\left(\mu_{i}^{\prime}\right)$ and the grain size $(D)$ increase with increasing Li content. It has been observed that the higher the $\mu_{i}^{\prime}$ is, the lower the resonance frequency in $\mathrm{Li}_{x} \mathrm{Cu}_{0.12} \mathrm{Mn}_{0.88-2 x} \mathrm{Fe}_{2+x} \mathrm{O}_{4}$ ferrites is.
\end{abstract}

\section{Introduction}

Ferrite nanoparticles have attracted a growing interest due to their potential applications such as magnetic recording [1], storage [2], and biotechnology [3]. In the most recent years, the interest in the use of nanoparticles in biomedical applications has greatly increased $[4,5]$. The size and composition of nanoparticles influence the bio-application of the magnetic nanoparticles [6]. It is well known that the physical and chemical properties of the nanosized magnetic materials are quite different from those of the bulk ones due to their surface effect and quantum confinement effects. These nanoparticles can be obtained through precipitation of metallic salts in different media as polymers [7], organic acid or alcohol [8], sugars [9], and so forth. In particular, sol-gel, autocombustion, thermal decomposition, hydrothermal, ball milling, reverse micelle synthesis, solid-phase reaction, thermally activated solid state reaction, and pulsed laser deposition have been developed to prepare the single-domain $\mathrm{MnFe}_{2} \mathrm{O}_{4}$ nanoparticles [10-23]. Manganese ferrite $\left(\mathrm{MnFe}_{2} \mathrm{O}_{4}\right)$ nanoparticles have become very popular due to their wide range of magnetic applications, such as recording devices, drug delivery, ferrofluid, biosensors, and catalysis [10, 24-27]. Recently, Deraz and
Alarifi [28] have studied structural and magnetic properties of $\mathrm{MnFe}_{2} \mathrm{O}_{4}$ nanoparticles by combustion route. Till now, no other report has been found in the literature for Li-doped $\mathrm{Cu}-\mathrm{Mn}$ ferrite. Lithium ferrites are low-cost materials which are attractive for microwave device applications. Hence, there has been a growing interest in Li-substituted $\mathrm{Cu}-\mathrm{Mn}$ ferrite for microwave applications and high permeability with low magnetic loss. Therefore, this paper is devoted to study the effect of $\mathrm{Li}^{+}$substitution on the physical and magnetic properties of $\mathrm{Li}_{x} \mathrm{Cu}_{0.12} \mathrm{Mn}_{0.88-2 x} \mathrm{Fe}_{2+x} \mathrm{O}_{4}$ ferrites prepared by combustion technique.

\section{Experimental}

2.1. Sample Preparation and Characterization. The $\mathrm{Li}_{x} \mathrm{Cu}_{0.12}$ $\mathrm{Mn}_{0.88-2 x} \mathrm{Fe}_{2+x} \mathrm{O}_{4}$ ferrites were prepared by autocombustion technique. The analytical grade of $\mathrm{Li}\left(\mathrm{NO}_{3}\right)_{2}, \mathrm{MnCl}_{2} \cdot 4 \mathrm{H}_{2} \mathrm{O}$, $\mathrm{Cu}\left(\mathrm{NO}_{3}\right)_{2} \cdot 3 \mathrm{H}_{2} \mathrm{O}$, and $\mathrm{Fe}\left(\mathrm{NO}_{3}\right)_{3} \cdot 9 \mathrm{H}_{2} \mathrm{O}$ was taken as raw material and weighted according to the stoichiometric amount and then dissolved in ethanol. The mixture was placed in a magnetic heating stirrer at $80^{\circ} \mathrm{C}$, followed by an ignition, the combustion takes place within a few seconds, 
and fine nanosized powders were precipitated. These powders were crushed and ground thoroughly. The fine powders of the composition were then calcined at $900^{\circ} \mathrm{C}$ for $5 \mathrm{~h}$ for the final formation of $\mathrm{Li}_{x} \mathrm{Cu}_{0.12} \mathrm{Mn}_{0.88-2 x} \mathrm{Fe}_{2+x} \mathrm{O}_{4}$ ferrites nanoparticles. Then, the fine powders were granulated using polyvinyl alcohol (PVA) as a binder and pressed uniaxially into diskshaped (about $13 \mathrm{~mm}$ outer diameter, $1.5 \mathrm{~mm}-2.0 \mathrm{~mm}$ thickness) and toroid-shaped (about $13 \mathrm{~mm}$ outer diameter, about $6.5 \mathrm{~mm}$ inner diameter and $2 \mathrm{~mm}$ thickness) samples. The samples prepared from each composition were sintered at $1200^{\circ} \mathrm{C}$ for 1 hour in air. The temperature ranges for sintering was maintained at $5^{\circ} \mathrm{C} / \mathrm{min}$ for heating and $10^{\circ} \mathrm{C} / \mathrm{min}$ for cooling. All sintered samples were polished and thermal etching was performed. X-ray diffraction was carried out with an X-ray diffractometer (Model: D8 Advance, Bruker AXS) for each sample. For this purpose, monochromatic $\mathrm{Cu}-\mathrm{K}_{\alpha}$ radiation was used. The lattice parameter for each peak of each sample was calculated by using the formula

$$
a_{0}=d \sqrt{h^{2}+k^{2}+l^{2}},
$$

where $h, k$, and $l$ are the indices of the crystal planes. To determine the exact lattice parameter for each sample, Nelson-Riley method was used. The Nelson-Riley function $F(\theta)$ is given as

$$
F(\theta)=\frac{1}{2}\left[\left(\frac{\operatorname{Cos}^{2} \theta}{\operatorname{Sin} \theta}\right)+\left(\frac{\operatorname{Cos}^{2} \theta}{\theta}\right)\right] .
$$

The values of lattice constant " $a$ " of all the peaks for a sample are plotted against $F(\theta)$. Then, using a least-square fit method exact lattice parameter " $a_{o}$ " was determined. The point where the least-square fit straight line cuts the $y$-axis (i.e., at $F(\theta)=0$ or $\theta=90^{\circ}$ ) is the actual lattice parameter of the sample.

The physical or bulk densities $\rho_{B}$ of the samples were determined by Archimedes principle with water medium using the following expression:

$$
\rho_{B}=\frac{W \rho}{W-W^{\prime}} \mathrm{g} / \mathrm{cm}^{3},
$$

where $W$ is the weight of the sample in air, $W^{\prime}$ is the weight of the sample in the water, and $\rho$ is the density of water in room temperature.

The theoretical density $\rho_{\text {th }}$ was calculated using the following expression:

$$
\rho_{\mathrm{th}}=\frac{8 M}{N_{A} a_{o}^{3}} \mathrm{~g} / \mathrm{cm}^{3},
$$

where $N_{A}$ is Avogadro's number $\left(6.02 \times 10^{23} \mathrm{~mol}^{-1}\right)$ and $M$ is the molecular weight.

The optical micrographs for various $\mathrm{Li}_{x} \mathrm{Cu}_{0.12} \mathrm{Mn}_{0.88-2 x}$ $\mathrm{Fe}_{2+x} \mathrm{O}_{4}$ ferrites have been taken by using high-resolution optical microscope (Model: NMM-800TRF). Average grain sizes of all samples were determined from optical micrographs by linear intercept technique [29]. The frequencydependent initial permeability for each sample was measured by using a Wayne Kerr Impedance Analyzer (Model: 6500B).
The complex permeability measurement on toroid-shaped samples was carried out at room temperature in frequency range $10 \mathrm{KHz}-100 \mathrm{MHz}$. Both the $\mu_{i}^{\prime}$ and $\mu_{i}^{\prime \prime}$ of the complex permeability were calculated using the following relations:

$$
\begin{gathered}
\mu_{i}^{\prime}=\frac{L_{s}}{L_{0}}, \\
\mu_{i}^{\prime \prime}=\mu_{i}^{\prime} \tan \delta,
\end{gathered}
$$

where $L_{s}$ is the self-inductance of the sample core and $L_{0}=\mu_{0} N^{2} S / \pi \bar{d}$ is derived geometrically. Here, $L_{0}$ is the inductance of the winding coil without the sample core, $N$ is the number of turns of the coil $(N=5)$, and $S$ is the area of cross-section of the toroidal sample as follows:

$$
S=d \times h
$$

where $d=\left(d_{2}-d_{1}\right) / 2, d_{1}=$ inner diameter, $d_{2}=$ outer diameter, $h=$ Height and $\bar{d}$ is the mean diameter of the toroidal sample as follows:

$$
\bar{d}=\frac{d_{1}+d_{2}}{2}
$$

The Loss factor, $\tan \delta$, was determined from the ratio $\left(=\mu_{i}^{\prime \prime} / \mu_{i}^{\prime}\right)$.

\section{Results and Discussion}

3.1. X-Ray Diffraction Analysis. The XRD analysis was performed to verify the formation of spinel structure of various $\mathrm{Li}_{x} \mathrm{Cu}_{0.12} \mathrm{Mn}_{0.88-2 x} \mathrm{Fe}_{2+x} \mathrm{O}_{4}$ ferrites, in which $\mathrm{Mn}^{2+}$ is replaced with $\mathrm{Li}^{+}$and $\mathrm{Fe}^{3+}$. The XRD patterns of these $\mathrm{Li}^{+}$substituted $\mathrm{Li}_{x} \mathrm{Cu}_{0.12} \mathrm{Mn}_{0.88-2 x} \mathrm{Fe}_{2+x} \mathrm{O}_{4}$ (with $x=0.00,0.10$, $0.20,0.30,0.40$, and 0.44 ) ferrites sintered at $1200^{\circ} \mathrm{C}$ in air for $1 \mathrm{~h}$ are shown in Figure 1 . The patterns indicated that these materials have a well-defined single crystalline phase and formation of cubic spinel structure for each composition. Analyzing the XRD patterns, it is observed that the positions of the peaks comply with the reported value [30] and some traces of raw materials were found for $x=0.00, x=0.10$ and $x=0.20$ and $x=0.30$ ).

3.2. Lattice Constant. The values of lattice constant obtained from each plane are plotted against Nelson-Riley function [31]. The values of lattice constant were estimated from the extrapolation of these lines to $F(\theta)=0$ or $\theta=90^{\circ}$. It is noticed from Figure 2 that $a_{0}$ increases with the increase of $\mathrm{Li}^{+}$content in $\mathrm{Li}_{x} \mathrm{Cu}_{0.12} \mathrm{Mn}_{0.88-2 x} \mathrm{Fe}_{2+x} \mathrm{O}_{4}$ (with $x=0.00$, $0.10,0.20,0.30,0.40$, and 0.44 ) ferrites. Values of $a_{0}$ for various $\mathrm{Li}_{x} \mathrm{Cu}_{0.12} \mathrm{Mn}_{0.88-2 x} \mathrm{Fe}_{2+x} \mathrm{O}_{4}$ ferrites are presented in Table 2 . The increase in $a_{0}$ with Li content indicates that the present system obeys Vegard's law [32]. This increase of $a_{0}$ can be attributed to the ionic size. The ionic radius of $\mathrm{Li}^{+}(0.76 \AA)$ is greater than that of $\mathrm{Mn}^{2+}(0.67 \AA)[29,33]$. When the larger $\mathrm{Li}^{+}$and $\mathrm{Fe}^{3+}$ ions enter the lattice, the unit cell expands while preserving the overall cubic symmetry. 


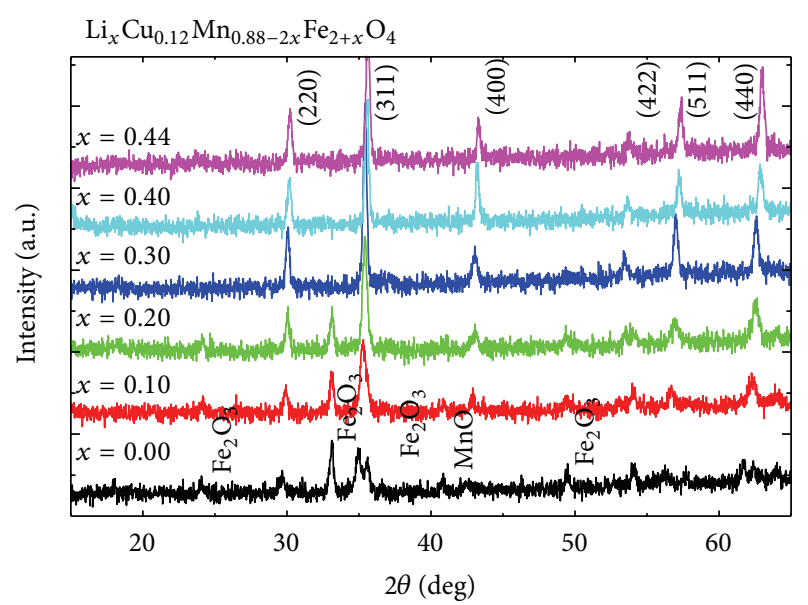

Figure 1: The X-ray diffraction patterns for various $\mathrm{Li}_{x} \mathrm{Cu}_{0.12}$ $\mathrm{Mn}_{0.88-2 x} \mathrm{Fe}_{2+x} \mathrm{O}_{4}$ sintered at $1200^{\circ} \mathrm{C}$.

3.3. Average Particle Size. The average particle size was estimated by using Debye-Scherrer [34] formula from the broadening of the highest intensity peaks (311) of XRD patterns:

$$
D=\frac{0.9 \lambda}{\beta \cos \theta},
$$

where $D$ is the average particle size, $\lambda$ is the wavelength of the radiation used as the primary beam of $\mathrm{Cu}-\mathrm{K}_{\alpha}(\lambda=$ $1.54178 \AA$ ), $\theta$ is the angle of the incident beam in degree, and $\beta$ is the full width at half maximum (FWHM) of the fundamental reflection (311) in radian of the FCC ferrites phase. Debye-Scherer formula assumes approximation and gives the average particle size if the grain size distribution is narrow and strain-induced effects are quite negligible.

Figure 3 shows the XRD patterns of $\mathrm{Li}_{x} \mathrm{Cu}_{0.12} \mathrm{Mn}_{0.88-2 x}$ $\mathrm{Fe}_{2+x} \mathrm{O}_{4}$ ferrites sintered at $1200^{\circ} \mathrm{C}$ for $1 \mathrm{~h}$, where (311) peak is shown in expanded form to understand the variation of FWHM of the Bragg peaks with the Li content. From Figure 3, it is seen that the value of FWHM decreases with the increase of lithium content. The particle size of the sample is inversely proportional to FWHM according to DebyeScherrer formula. The observed particle size is in the range from 9 to $30 \mathrm{~nm}$ which has been listed in Table 1 .

3.4. Theoretical and Bulk Density. The values of $\rho_{\text {th }}$ and $\rho_{B}$ for the various $\mathrm{Li}_{x} \mathrm{Cu}_{0.12} \mathrm{Mn}_{0.88-2 x} \mathrm{Fe}_{2+x} \mathrm{O}_{4}$ ferrites (with $x=$ $0.00,0.10,0.20,0.30,0.40$, and 0.44 ) are tabulated in Table 2. It is noticed from Figure 4 that both $\rho_{\mathrm{th}}$ and $\rho_{B}$ decrease with the increase of $\mathrm{Li}$ substitution in $\mathrm{Li}_{x} \mathrm{Cu}_{0.12} \mathrm{Mn}_{0.88-2 x} \mathrm{Fe}_{2+x} \mathrm{O}_{4}$ ferrites for constant sintering temperature. This phenomenon could be explained in terms of the atomic weight.The atomic weight of Mn (54.94 amu) is greater than that of combined atomic weight of the $\mathrm{Li}(6.941 \mathrm{amu})$ and $\mathrm{Fe}(55.845 \mathrm{amu})$ [33].

3.5. Microstructure. The optical micrographs of $\mathrm{Li}_{x} \mathrm{Cu}_{0.12}$ $\mathrm{Mn}_{0.88-2 x} \mathrm{Fe}_{2+x} \mathrm{O}_{4}$ ferrites (where $x=0.00, x=0.10, x=0.20$, $x=0.30, x=0.40$, and $x=0.44$ ) are shown in Figure 5 sintered

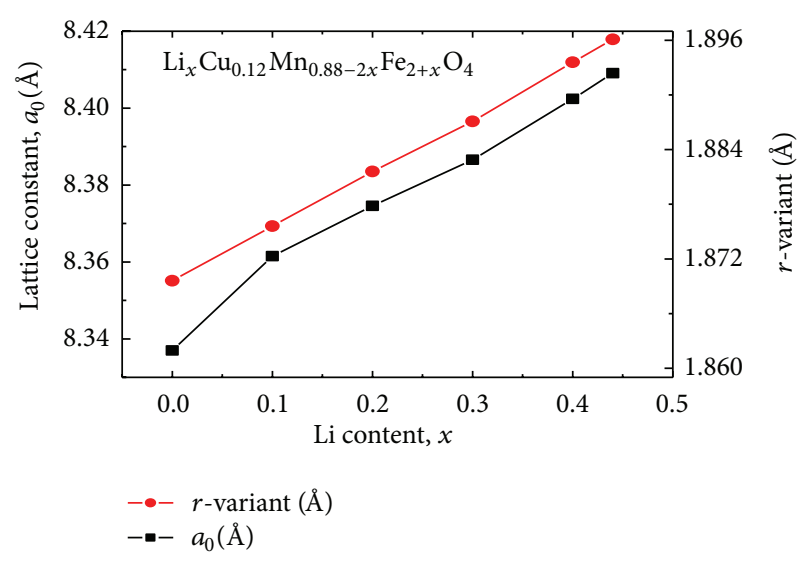

FIGURE 2: Variation of lattice constant and $r$-variant with Li content for various $\mathrm{Li}_{x} \mathrm{Cu}_{0.12} \mathrm{Mn}_{0.88-2 x} \mathrm{Fe}_{2+x} \mathrm{O}_{4}$ sintered at $1200^{\circ} \mathrm{C}$.

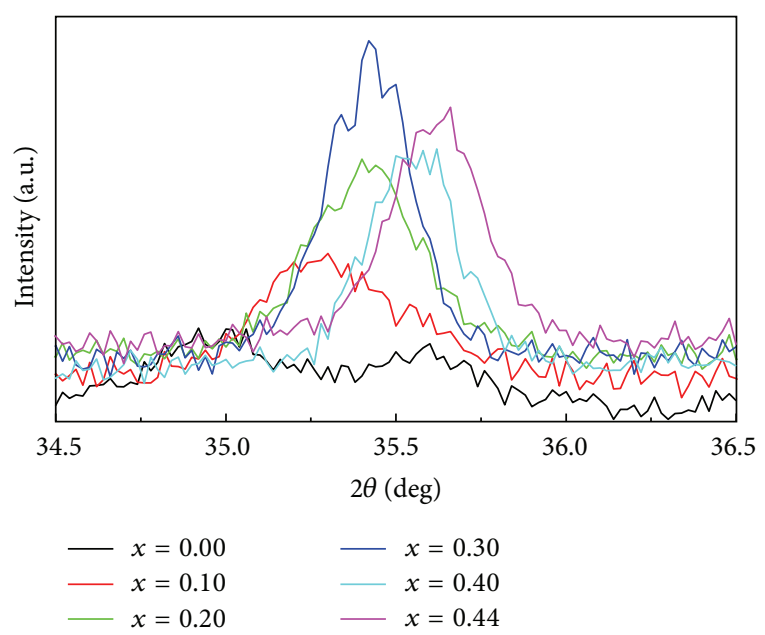

FIGURE 3: XRD patterns of (311) peak with Li content, for various $\mathrm{Li}_{x} \mathrm{Cu}_{0.12} \mathrm{Mn}_{0.88-2 x} \mathrm{Fe}_{2+x} \mathrm{O}_{4}$ nanoparticles.

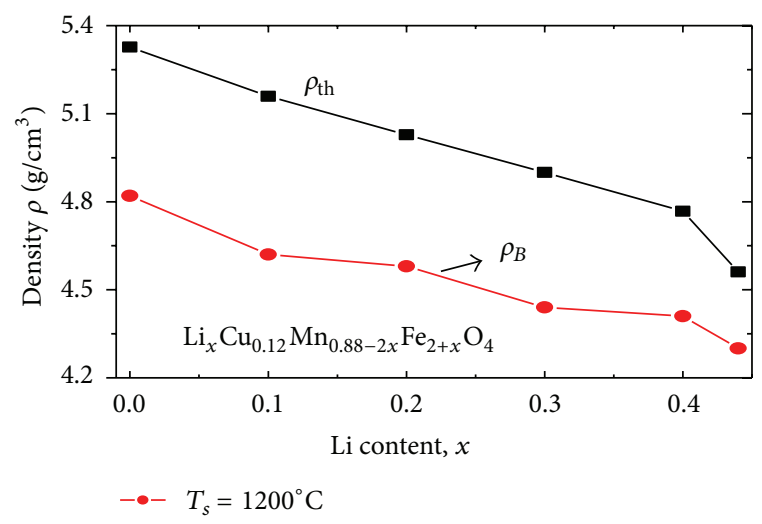

FIGURE 4: The variation of theoretical density and bulk density with $\mathrm{Li}$ content for various $\mathrm{Li}_{x} \mathrm{Cu}_{0.12} \mathrm{Mn}_{0.88-2 x} \mathrm{Fe}_{2+x} \mathrm{O}_{4}$. 
$x=0.00$

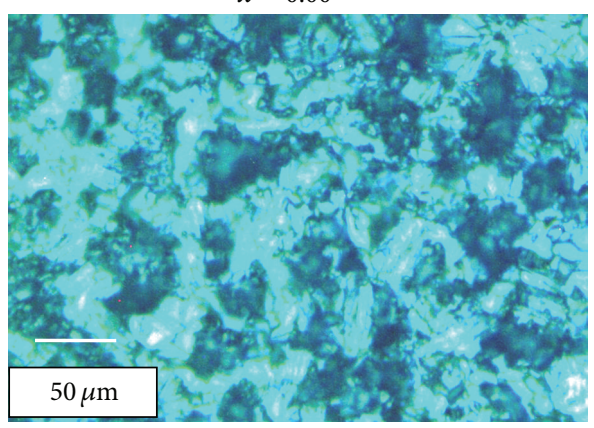

$x=0.20$

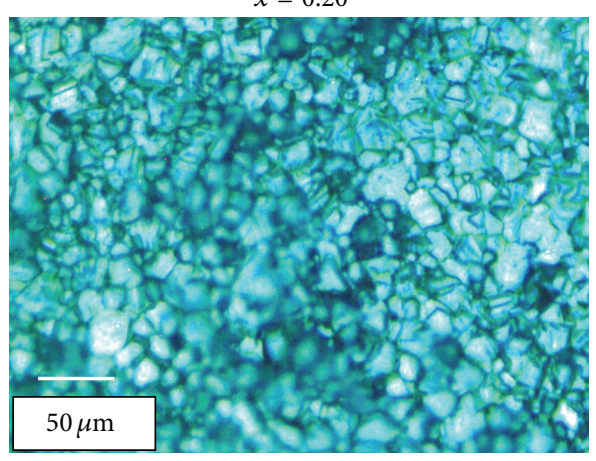

$x=0.40$

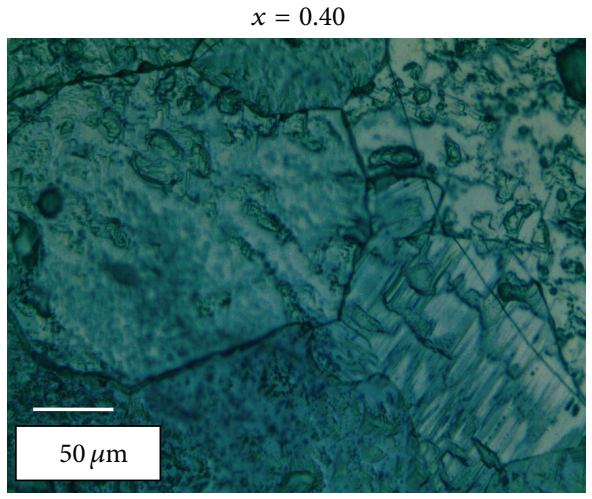

$x=0.10$

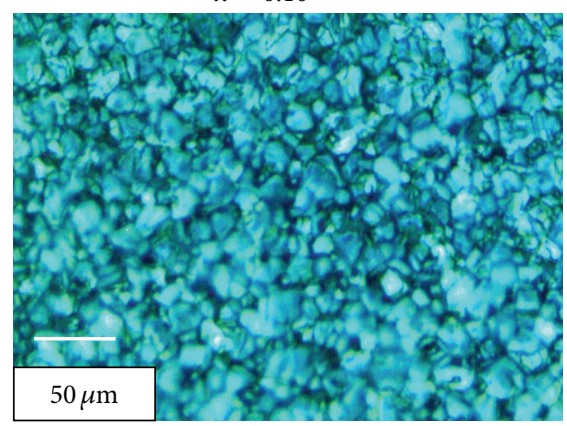

$x=0.30$

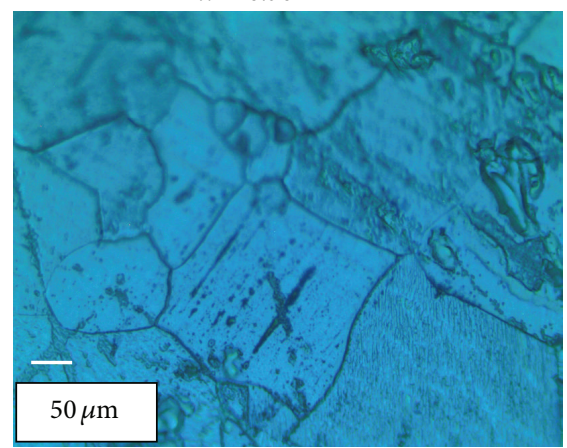

$x=0.44$

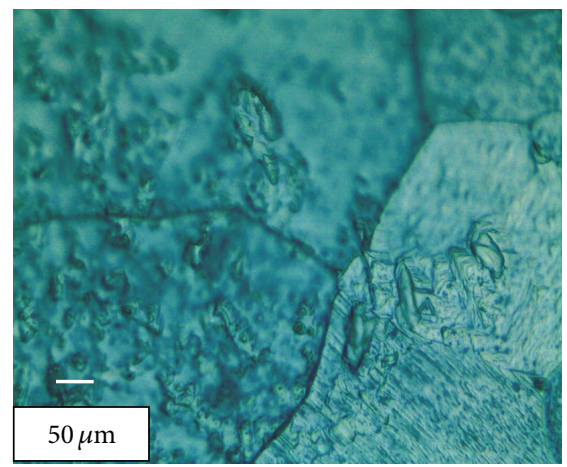

FIgURE 5: The optical micrographs of $\mathrm{Li}_{x} \mathrm{Cu}_{0.12} \mathrm{Mn}_{0.88-2 x} \mathrm{Fe}_{2+x} \mathrm{O}_{4}$ sintered at $1200^{\circ} \mathrm{C}$.

at $1200^{\circ} \mathrm{C}$. The grain size $(D)$ is significantly dependent on $\mathrm{Li}$ substitution. The $D$ increases with increasing Li substitution for fixed sintering temperature which is shown in Figure 5. This is probably due to the lower melting temperature of $\mathrm{Li}$ $\left(180^{\circ} \mathrm{C}\right)$ compared to $\mathrm{Mn}\left(1245^{\circ} \mathrm{C}\right)$. The values of $D$ for various $\mathrm{Li}_{x} \mathrm{Cu}_{0.12} \mathrm{Mn}_{0.88-2 x} \mathrm{Fe}_{2+x} \mathrm{O}_{4}$ ferrites are presented in Table 2.

3.6. Complex Initial Permeability. The compositional variations of complex initial permeability spectra for the various $\mathrm{Li}_{x} \mathrm{Cu}_{0.12} \mathrm{Mn}_{0.88-2 x} \mathrm{Fe}_{2+x} \mathrm{O}_{4}$ samples sintered at $1200^{\circ} \mathrm{C}$ are shown in Figure 6. It is observed that the $\mu_{i}^{\prime}$ remains fairly constant in the frequency range up to some critical frequency which is called resonance frequency, $f_{r}$. A sharp decrease in $\mu_{i}^{\prime}$ and increase in $\mu_{i}^{\prime \prime}$ are observed above the $f_{r}$. The $\mu_{i}^{\prime}$ increases with the increase of $\mathrm{Li}^{+}$content for various $\mathrm{Li}_{x} \mathrm{Cu}_{0.12} \mathrm{Mn}_{0.88-2 x} \mathrm{Fe}_{2+x} \mathrm{O}_{4}$. On the other hand, $f_{r}$ was found to decrease with $\mathrm{Li}$ substitution. It was observed that $\mu_{i}^{\prime}$ of $\mathrm{Li}_{x} \mathrm{Cu}_{0.12} \mathrm{Mn}_{0.88-2 x} \mathrm{Fe}_{2+x} \mathrm{O}_{4}$ ferrites sintered at $1200^{\circ} \mathrm{C}$ increases from 18 to 55 . Figure 7 shows both $\mu_{i}^{\prime}$ and $D$ as a function of $\mathrm{Li}$ content for various $\mathrm{Li}_{x} \mathrm{Cu}_{0.12} \mathrm{Mn}_{0.88-2 x} \mathrm{Fe}_{2+x} \mathrm{O}_{4}$ ferrites. According to Globus and Duplex model [35], the $\mu_{i}^{\prime}$ can be explained as $\mu_{i}^{\prime}=M_{s}^{2} D / \sqrt{K}$, where $M_{s}$ is the saturation magnetization and $K$ is the magnetocrystalline anisotropy constant. This increase in permeability is expected, because grain size of all samples increases with Li content. It is known that the mobility of domain walls is greatly affected by the microstructure of ferrites. Therefore, in the present case, variation of the initial permeability may be influenced by its grain size.

The variation of loss factor, $\tan \delta\left(=\mu_{i}^{\prime \prime} / \mu_{i}^{\prime}\right)$ with frequency for all samples, has been studied. The variation of initial loss with frequency for the various $\mathrm{Li}_{x} \mathrm{Cu}_{0.12} \mathrm{Mn}_{0.88-2 x} \mathrm{Fe}_{2+x} \mathrm{O}_{4}$ samples sintered at $1200^{\circ} \mathrm{C}$ is shown in Figure 8. At lower frequencies magnetic loss is observed and remains constant up to, a certain frequency, 


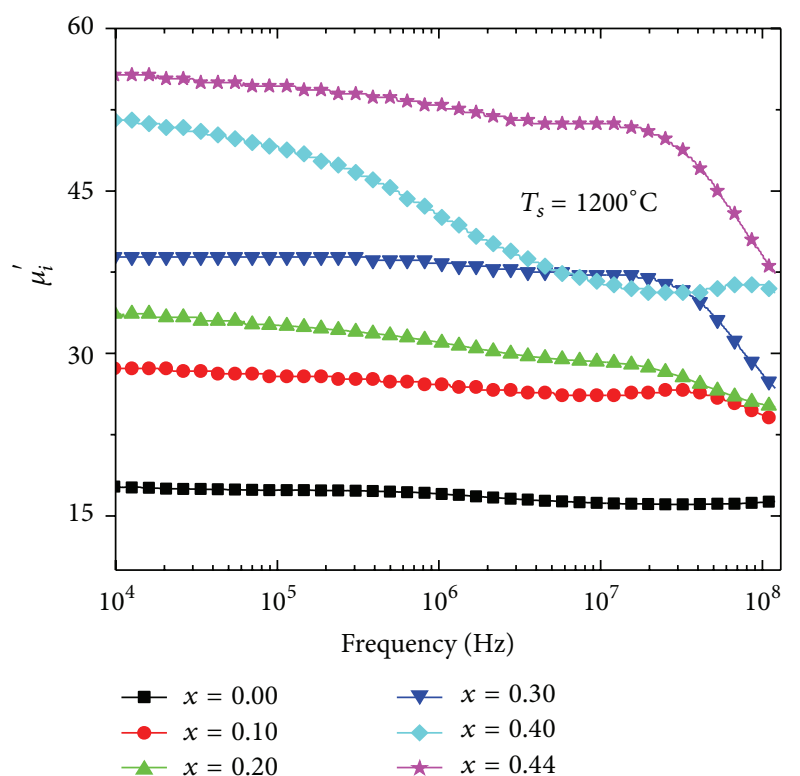

(a)

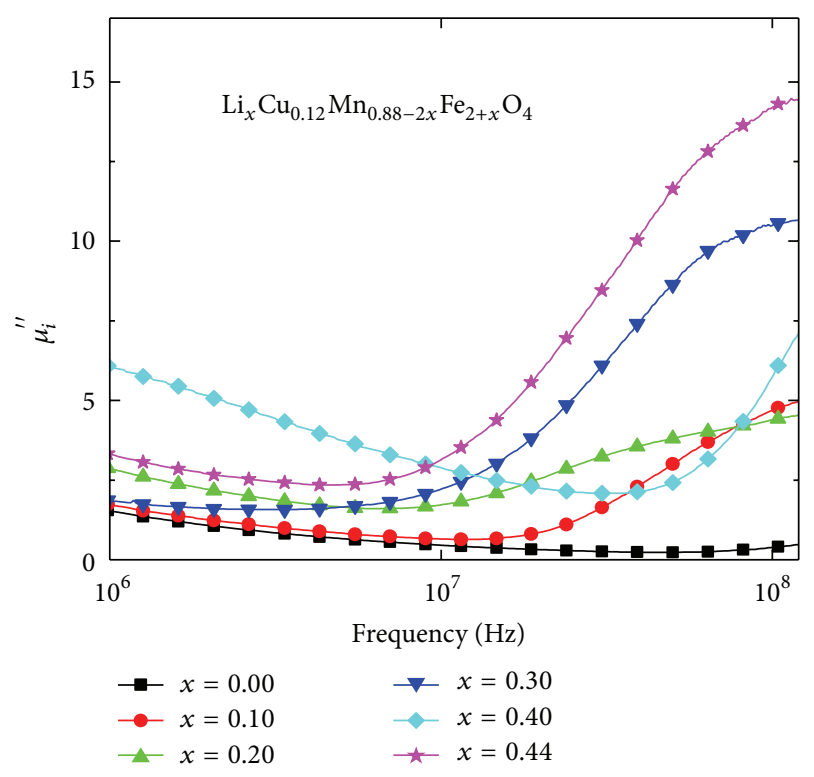

(b)

Figure 6: The $\mu_{i}^{\prime}$ and $\mu_{i}^{\prime \prime}$ for various $\mathrm{Li}_{x} \mathrm{Cu}_{0.12} \mathrm{Mn}_{0.88-2 x} \mathrm{Fe}_{2+x} \mathrm{O}_{4}$ ferrites sintered at $1200^{\circ} \mathrm{C}$ as function of frequency.

TABLE 1: Particle size and FWHM of $\mathrm{Li}_{x} \mathrm{Cu}_{0.12} \mathrm{Mn}_{0.88-2 x} \mathrm{Fe}_{2+x} \mathrm{O}_{4}$ nanoparticles.

\begin{tabular}{lcc}
\hline$x$ & FWHM (in degree) & Particle size $(\mathrm{nm})$ \\
\hline 0.00 & 0.015379 & 9.4 \\
0.10 & 0.00733 & 19 \\
0.20 & 0.006109 & 23 \\
0.30 & 0.004712 & 30 \\
0.40 & 0.004887 & 30 \\
0.44 & 0.005411 & 27 \\
\hline
\end{tabular}

$9 \mathrm{MHz}$; this frequency limit depends upon the sintering temperatures. The lag of domain wall motion with respect

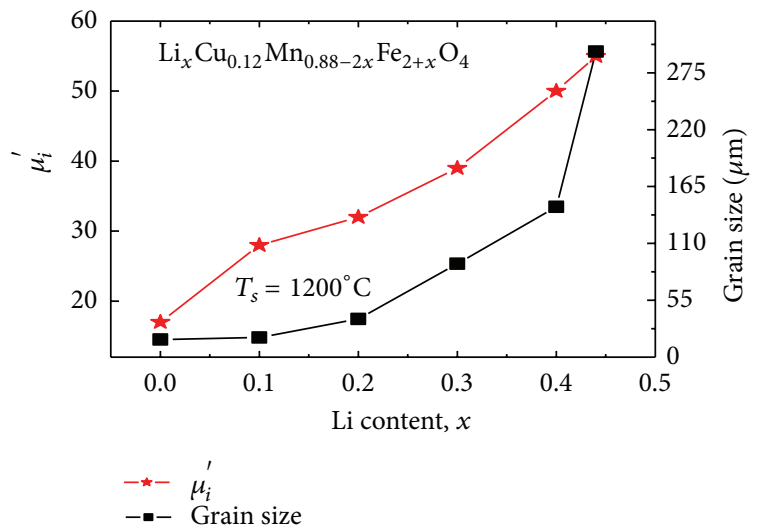

FIgURE 7: The $\mu_{i}^{\prime}$ and grain size with $\mathrm{Li}$ content for various $\mathrm{Li}_{x} \mathrm{Cu}_{0.12} \mathrm{Mn}_{0.88-2 x} \mathrm{Fe}_{2+x} \mathrm{O}_{4}$ sintered at $1200^{\circ} \mathrm{C}$.

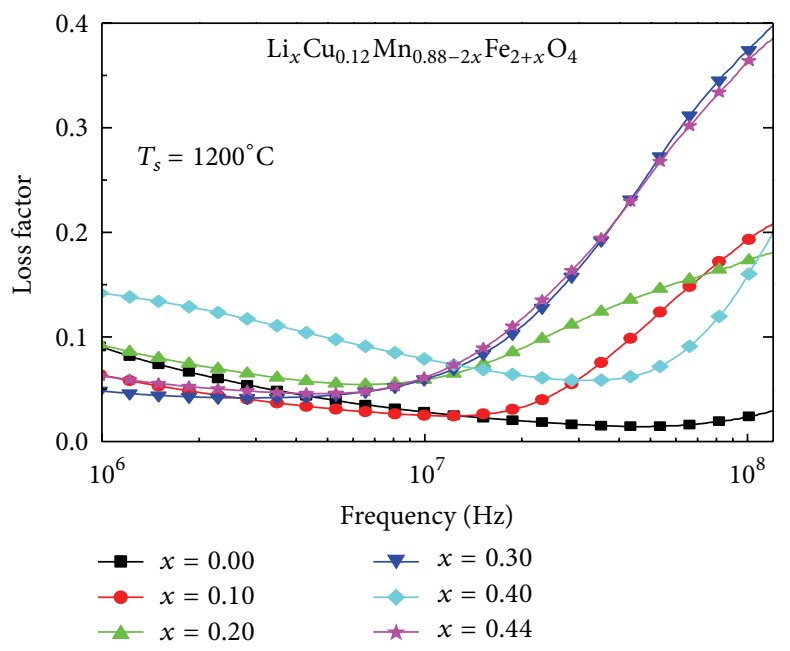

Figure 8: Loss factor as a function of frequency for various $\mathrm{Li}_{x} \mathrm{Cu}_{0.12} \mathrm{Mn}_{0.88-2 x} \mathrm{Fe}_{2+x} \mathrm{O}_{4}$ sintered at $1200^{\circ} \mathrm{C}$.

TABLE 2: The lattice parameter, density, average grain size, and initial permeability of $\mathrm{Li}_{x} \mathrm{Cu}_{0.12} \mathrm{Mn}_{0.88-2 x} \mathrm{Fe}_{2+x} \mathrm{O}_{4}$ sintered at $1200^{\circ} \mathrm{C}$.

\begin{tabular}{lccccc}
\hline$x$ & $a_{o}(\AA)$ & $\rho_{\mathrm{th}}\left(\mathrm{g} / \mathrm{cm}^{3}\right)$ & $\begin{array}{c}\rho_{B} \\
\left(\mathrm{~g} / \mathrm{cm}^{3}\right)\end{array}$ & $D(\mu \mathrm{m})$ & $\mu_{i}^{\prime}($ at $10 \mathrm{KHz})$ \\
\hline 0.00 & 8.3370 & 5.32 & 4.82 & 17.92 & 18 \\
0.10 & 8.3615 & 5.15 & 4.62 & 19 & 22 \\
0.20 & 8.3746 & 5.02 & 4.58 & 39 & 33 \\
0.30 & 8.3866 & 4.90 & 4.44 & 92 & 39 \\
0.40 & 8.4024 & 4.76 & 4.41 & 145.45 & 50 \\
0.44 & 8.4091 & 4.56 & 4.30 & 295.45 & 55 \\
\hline
\end{tabular}

to the applied magnetic field is responsible for magnetic loss and this is accredited to lattice imperfections [36]. At higher frequencies, a rapid increase in loss factor is observed. A resonance loss peak is shown in this rapid increase of magnetic loss. At the resonance, maximum energy transfer occurs from the applied field to the lattice which results in the rapid increases in loss factor. 


\section{Conclusion}

The $\mathrm{Li}_{x} \mathrm{Cu}_{0.12} \mathrm{Mn}_{0.88-2 x} \mathrm{Fe}_{2+x} \mathrm{O}_{4}(x=0.00$ to $x=0.44)$ nanoparticles have been successfully synthesized by the combustion technique. The observed particle size is in the range from $9 \mathrm{~nm}$ to $30 \mathrm{~nm}$. The XRD patterns confirm that the compositions are single phase and form cubic spinel structure. The lattice parameter increases linearly with increasing $\mathrm{Li}$ content and obeys Vegard's law. The study of microstructure shows that grain size increases with increasing $\mathrm{Li}$ content. The bulk density decreases with increasing Li substitution in $\mathrm{Li}_{x} \mathrm{Cu}_{0.12} \mathrm{Mn}_{0.88-2 x} \mathrm{Fe}_{2+x} \mathrm{O}_{4}$ ferrites. The real part of initial permeability increases with increase of Li content for a fixed sintering temperature. This result may be explained with the help of average grain size. The highest $\mu_{i}^{\prime}$ was found 55 for $x=0.44$ which is three times greater than that of parent composition. It was also observed that the resonance frequency, $f_{r}$, and real part of initial permeability, $\mu_{i}^{\prime}$, are inversely proportional which confirms Snoek's relation, $f_{r} \mu_{i}^{\prime}=$ constant.

\section{Acknowledgments}

The authors are grateful to the BUET authority for providing financial support for this research. The authors are also thankful to the authority of BCSIR for using their equipment.

\section{References}

[1] M. Suda, M. Nakagawa, T. Iyoda, and Y. Einaga, "Reversible photoswitching of ferromagnetic FePt nanoparticles at room temperature," Journal of the American Chemical Society, vol. 129, no. 17, pp. 5538-5543, 2007.

[2] B. O. Regan and M. Gratzel, "A low-cost, high-efficiency solar cell based on dye-sensitized colloidal $\mathrm{TiO}_{2}$ films," Nature, vol. 353, pp. 737-740, 1991.

[3] M. Shinkai, "Functional magnetic particles for medical application," Journal of Bioscience and Bioengineering, vol. 94, no. 6, pp. 606-613, 2002.

[4] C. C. Berry and A. S. G. Curtis, "Functionalisation of magnetic nanoparticles for applications in biomedicine," Journal of Physics D, vol. 36, no. 13, article R198, 2003.

[5] S. Mornet, S. Vasseur, F. Grasset, and E. Duguet, "Magnetic nanoparticle design for medical diagnosis and therapy," Journal of Materials Chemistry, vol. 14, no. 14, pp. 2161-2175, 2004.

[6] C. Corot, P. Robert, J. M. Ideé, and M. Port, "Recent advances in iron oxide nanocrystal technology for medical imaging," Advanced Drug Delivery Reviews, vol. 58, no. 14, pp. 1471-1504, 2006.

[7] J.-F. Berret, N. Schonbeck, F. Gazeau et al., "Controlled clustering of superparamagnetic nanoparticles using block copolymers: design of new contrast agents for magnetic resonance imaging," Journal of the American Chemical Society, vol. 128, no. 5, pp. 1755-1761, 2006.

[8] C. Sun, R. Size, and M. Zhang, "Folic acid-PEG conjugated superparamagnetic nanoparticles for targeted cellular uptake and detection by MRI," Journal of Biomedical Materials Research A, vol. 78, no. 3, pp. 550-557, 2006.
[9] R. Y. Hong, B. Feng, L. L. Chen, G. H. Li, Y. Zeng, and D. G. Wei, "Synthesis, characterization and MRI application of dextrancoated $\mathrm{Fe}_{3} \mathrm{O}_{4}$ magnetic nanoparticles," Biochemical Engineering Journal, vol. 42, no. 3, pp. 290-300, 2008.

[10] N. M. Deraz and S. Shaban, "Optimization of catalytic, surface and magnetic properties of nanocrystalline manganese ferrite," Journal of Analytical and Applied Pyrolysis, vol. 86, pp. 173-179, 2009.

[11] M. A. Ahmed, N. Okasha, and M. M. El-Sayed, "Enhancement of the physical properties of rare-earth-substituted $\mathrm{Mn}-\mathrm{Zn}$ ferrites prepared by flash method," Ceramics International, vol. 33, no. 1, pp. 49-58, 2007.

[12] Q. M. Wei, J.-B. Li, Y.-J. Chen, and Y.-S. Han, "X-ray study of cation distribution in $\mathrm{NiMn}_{1-x} \mathrm{Fe}_{2-x} \mathrm{O}_{4}$ ferrites," Materials Characterization, vol. 47, no. 3-4, pp. 247-252, 2001.

[13] M. H. Mahmoud, H. H. Hamdeh, J. C. Ho, M. J. O’Shea, and J. C. Walker, "Moessbauer studies of manganese ferrite fine particles processed by ball-milling," Journal of Magnetism and Magnetic Materials, vol. 220, no. 2, pp. 139-146, 2000.

[14] M. Muroi, R. Street, P. G. McCormick, and J. Amighian, "Magnetic properties of ultrafine $\mathrm{MnFe}_{2} \mathrm{O}_{4}$ powders prepared by mechanochemical processing," Physical Review B, vol. 63, no. 18, Article ID 184414, 2001.

[15] C. Li and Z. J. Zhang, "Size-dependent superparamagnetic properties of Mn spinel ferrite nanoparticles synthesized from reverse micelles," Chemistry of Materials, vol.13, no. 6, pp. 20922096, 2001.

[16] M. H. Mahmoud, C. M. Williams, J. Cai, I. Siu, and J. C. Walker, "Investigation of $\mathrm{Mn}$-ferrite films produced by pulsed laser deposition," Journal of Magnetism and Magnetic Materials, vol. 261, no. 3, pp. 314-318, 2003.

[17] C. Alvani, G. Ennas, A. La Barbera, G. Marongiu, F. Padella, and F. Varsano, "Synthesis and characterization of nanocrystalline $\mathrm{MnFe}_{2} \mathrm{O}_{4}$ : advances in thermochemical water splitting," International Journal of Hydrogen Energy, vol. 30, no. 13-14, pp. 14071411, 2005.

[18] D. Carta, M. F. Casula, A. Falqui et al., "A structural and magnetic investigation of the inversion degree in ferrite nanocrystals $\mathrm{MFe}_{2} \mathrm{O}_{4}(\mathrm{M}=\mathrm{Mn}, \mathrm{Co}, \mathrm{Ni})$," Journal of Physical Chemistry C, vol. 113, no. 20, pp. 8606-8615, 2009.

[19] Y. Liu, Y. Zhang, J. D. Feng, C. F. Li, J. Shi, and R. Xiong, "Dependence of magnetic properties on crystallite size of $\mathrm{CoFe}_{2} \mathrm{O}_{4}$ nanoparticles synthesised by auto-combustion method," Journal of Experimental Nanoscience, vol. 4, no. 2, pp. 159-168, 2009.

[20] C. Cannas, A. Musinu, D. Peddis, and G. Piccaluga, "Synthesis and characterization of $\mathrm{CoFe}_{2} \mathrm{O}_{4}$ nanoparticles dispersed in a silica matrix by a sol-gel autocombustion method," Chemistry of Materials, vol. 18, no. 16, pp. 3835-3842, 2006.

[21] C. Cannas, A. Falqui, A. Musinu, D. Peddis, and G. Piccaluga, " $\mathrm{CoFe}_{2} \mathrm{O}_{4}$ nanocrystalline powders prepared by citrate-gel methods: synthesis, structure and magnetic properties," Journal of Nanoparticle Research, vol. 8, no. 2, pp. 255-267, 2006.

[22] L.J. Zhao, H.J. Zhang, Y. Xing et al., "Studies on the magnetism of cobalt ferrite nanocrystals synthesized by hydrothermal method," Journal of Solid State Chemistry, vol. 181, no. 2, pp. 245$252,2008$.

[23] Q. Liu, J.H. Sun, H.R. Long, X.Q. Sun, X.J. Zhong, and Z. $\mathrm{Xu}$, "Hydrothermal synthesis of $\mathrm{CoFe}_{2} \mathrm{O}_{4}$ nanoplatelets and nanoparticles," Materials Chemistry and Physics, vol. 108, no. 23, pp. 269-273, 2008.

[24] S. R. Ahmed, S. B. Ogale, G. C. Papaefthymiou, R. Ramesh, and $\mathrm{P}$. Kofinas, "Magnetic properties of $\mathrm{CoFe}_{2} \mathrm{O}_{4}$ nanoparticles 
synthesized through a block copolymer nanoreactor route," Applied Physics Letters, vol. 80, no. 9, pp. 1616-1618, 2002.

[25] I. Brigger, C. Dubernet, and P. Couvreur, "Nanoparticles in cancer therapy and diagnosis," Advanced Drug Delivery Reviews, vol. 54, no. 5, pp. 631-651, 2002.

[26] R. Arulmurugan, G. Vaidyanathan, S. Sendhilnathan, and B. Jeyadevan, "Mn-Zn ferrite nanoparticles for ferrofluid preparation: study on thermal-magnetic properties," Journal of Magnetism and Magnetic Materials, vol. 298, no. 2, pp. 83-94, 2006.

[27] J. B. Haun, T. J. Yoon, H. Lee, and R. Weissleder, "Magnetic nanoparticle biosensors," Wiley Interdisciplinary Reviews, vol. 2, no. 3, pp. 291-304, 2010.

[28] N. M. Deraz and A. Alarifi, "Controlled synthesis, physicochemical and magnetic properties of nano-crystalline $\mathrm{Mn}$ ferrite system," International Journal of Electrochemical Science, vol. 7, pp. 5534-5543, 2012.

[29] M. I. Mendelson, "Average grain size in polycrystalline ceramics," Journal of the American Ceramic Society, vol. 52, no. 8, pp. 443-446, 1969.

[30] C. Rath, S. Anand, R. P. Das et al., "Dependence on cation distribution of particle size, lattice parameter, and magnetic properties in nanosize $\mathrm{Mn}-\mathrm{Zn}$ ferrite," Journal of Applied Physics, vol. 91, no. 4, article 2211, 2002.

[31] J. B. Nelson and D. P. Riley, "An experimental investigation of extrapolation methods in the derivation of accurate unit-cell dimensions of crystals," Proceedings of the Physical Society, vol. 57, no. 3, pp. 160-177, 1945.

[32] L. Vegard, "The constitution of mixed crystal and the space occupied by atom," Zeitschrift für Physik, no. 17, pp. 17-26, 1921.

[33] M. J. Winter, University of Sheffield, Yorkshire, UK, 1995-2006, http://www.webelements.com/.

[34] B. D. Cullity, Elements of X-Ray Diffraction, Addison-Wesley, Reading, Mass, USA, 3rd edition, 1972.

[35] A. Globus, P. Duplex, and G. M. Guyot, "Determination of initial magnetization curve from crystallites size and effective anisotropy field," IEEE Transactions on Magnetics, vol. 7, no. 3, pp. 617-622, 1971.

[36] J. L. Snoek, "Dispersion and absorption in magnetic ferrites at frequencies above one Mc/s," Physica, vol. 17, no. 4, pp. 207-217, 1948. 

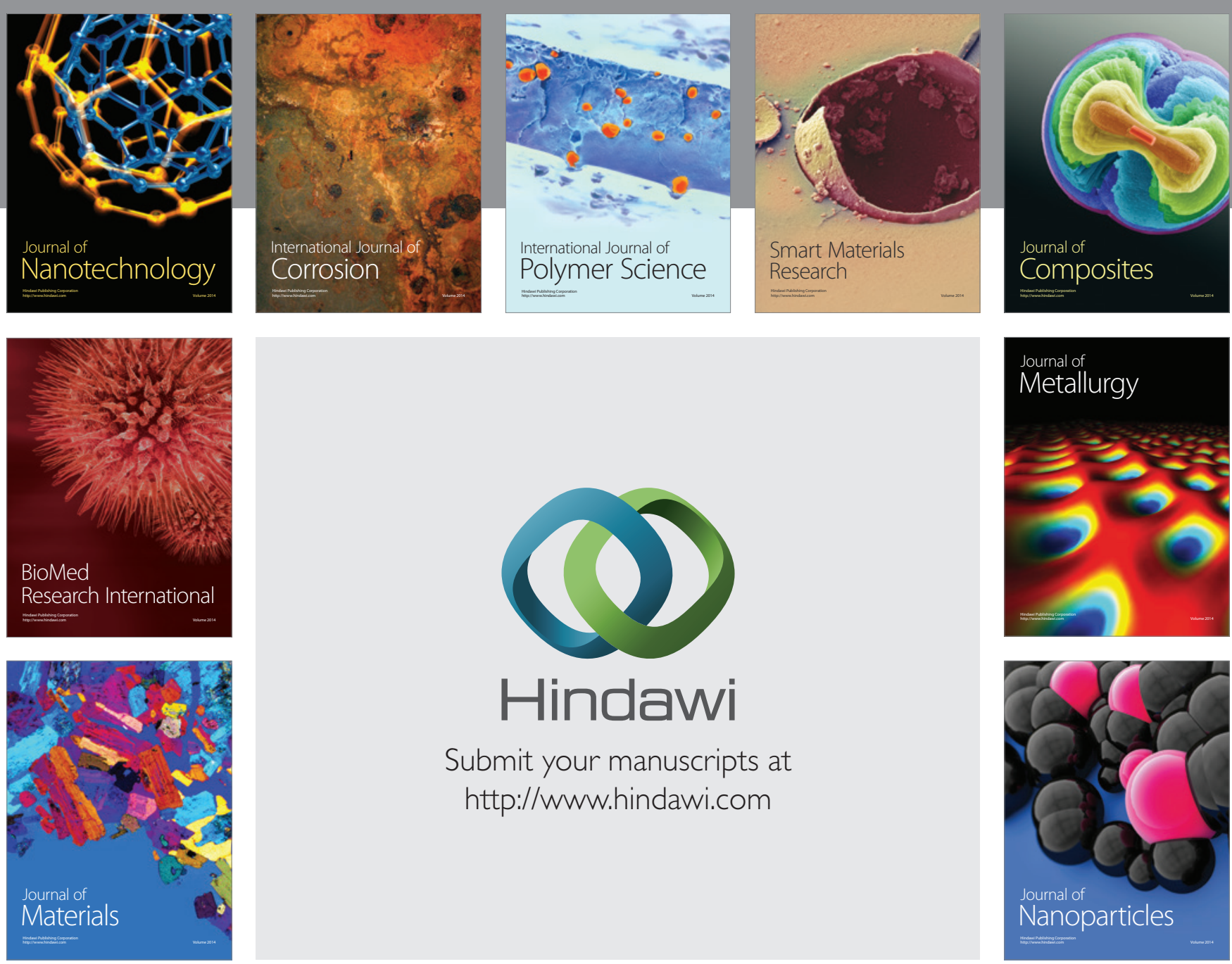

Submit your manuscripts at http://www.hindawi.com
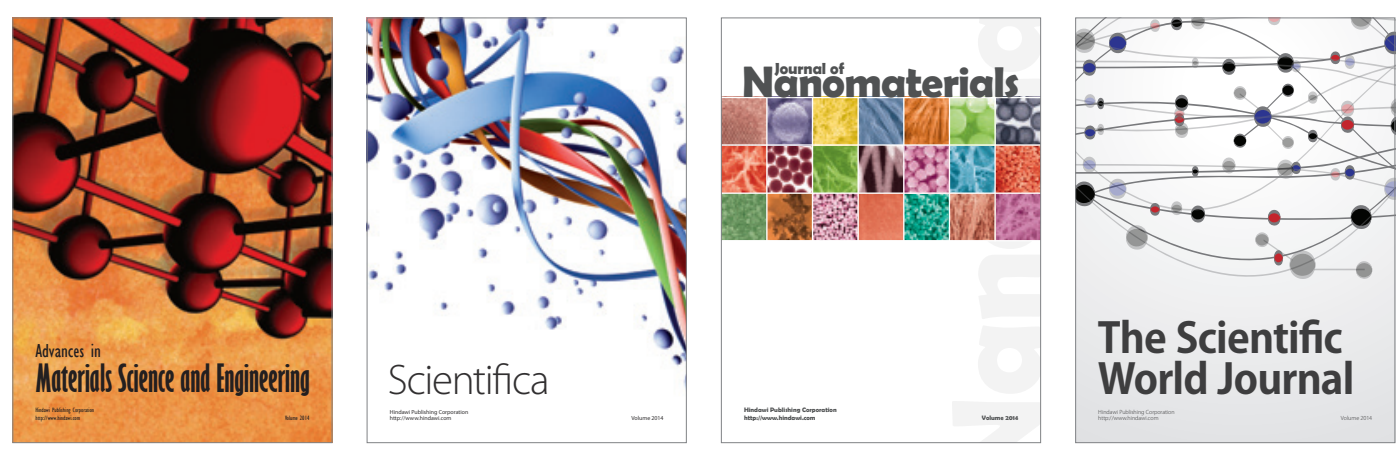

\section{The Scientific World Journal}
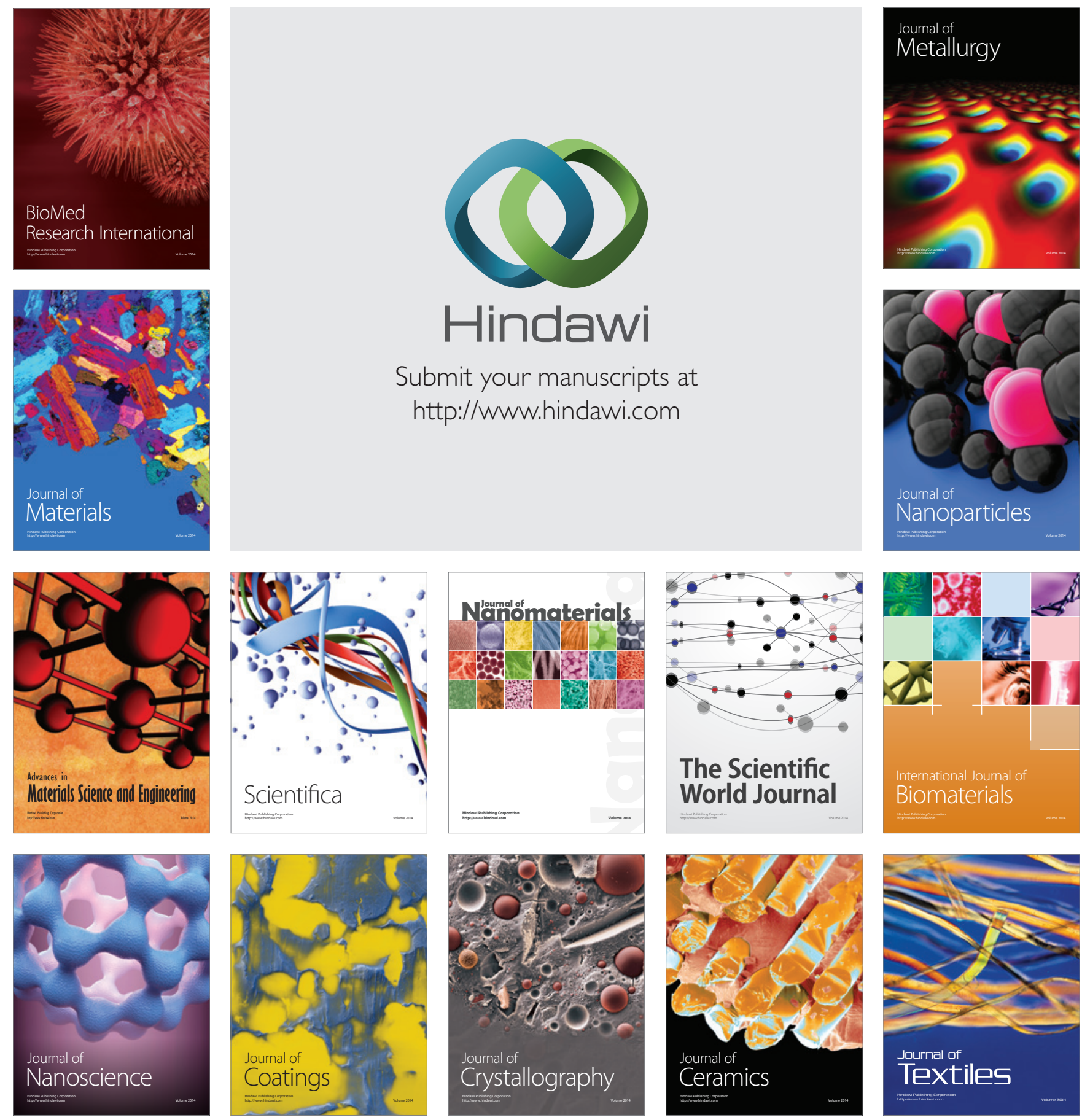